\title{
Leaf anatomical traits of Crataegus orientalis Pall. ex M.Bieb. (Rosaceae) from Turkey
}

\author{
Zeynep Büşra ERARSLAN 1 * (D), Şükran KÜLTÜR 1 (iD) \\ 1 Department of Pharmaceutical Botany, Faculty of Pharmacy, İstanbul University, 34116, İstanbul, Turkey. \\ * Corresponding Author. E-mail: zeynepberarslan@gmail.com (Z.B.E.); Tel. +90 2123801768.
}

Received: 12 April 2019 / Revised: 15 June 2019 / Accepted: 20 June 2019

\begin{abstract}
Crataegus orientalis Pall. ex M.Bieb., is a widespread species of the genus Crataegus L. (Rosaceae), which has an important place in traditional folk medicine. In this study, Crataegus orientalis subsp. orientalis and Crataegus orientalis subsp. szovitsii (Pojark.) K.I.Chr. from Turkey were investigated with regard to leaf anatomy. For this reason, transverse sections and surficial sections were taken from samples. Leaves of the both taxa was found as dorsiventral, hypostomatic and mesomorphic. Cyclocytic type stomata, simple single non-glandular trichomes and calcium oxalate crystals were defined as significant anatomical features of these taxa. All results were compared with leaf anatomical features of the Rosaceae family and the characteristics of the genus Crataegus were elucidated by detecting similarities and differences.
\end{abstract}

KEYWORDS: Crataegus orientalis; Rosaceae; leaf anatomy; Turkey.

\section{INTRODUCTION}

The genus Crataegus L. is placed in the tribe Maleae Small, subfamily Maloideae C. Weber of the Rosaceae family based on the latest nomenclatural changes [1,2], and is represented by over 200 species widely distributed in Western Asia, North America and Europe. In addition, some of them are widely cultivated as ornamental plants [3,4]. In Turkey, this genus comprises 28 taxa corresponding to 24 different species, 10 of which are endemic [5]. The most significant taxonomic characters of Crataegus are indumentum, teeths and shape of leaves. Additionally, members of this genus exhibit yellow-red fruits and greenish calyx [6,7]. According to Dönmez [7], the taxonomy of Crataegus is a difficult issue because of the polymorphic characters, hybridisation, inadequate collections and deficiency of field observations. Crataegus orientalis Pall. ex M.Bieb is one of the most widely used species of this genus traditionally. It is a shrub or small tree usually $3-5 \mathrm{~m}$ tall. Leaves are obovate-oblong and deeply 3 - 7 lobed with adpressed grey hairs. Flowers are arranged in 4 - 10 flowered corymbs; sepals are $4-5 \mathrm{~mm}$ long, triangular-cuspidate, reflexed in fruit. Reddish-orange fruits are about $2 \mathrm{~cm}$ in diameter [6,8]. This species is represented by two subspecies in Turkey: Crataegus orientalis subsp. orientalis and Crataegus orientalis subsp. szovitsii (Pojark.) K.I.Chr. Defined differences between the two subspecies [6,8,9] are:

1. Fruit reddish-orange, pyrenes $4(-5)$; sepals reflexed in fruit ......... C. orientalis subsp. orientalis

2. Fruit red, pyrenes (2-) $3-4$; sepals spreading in fruit ........... C. orientalis subsp. szovitsii (Figure 1)

C. orientalis subsp. orientalis is widespread in Turkey, especially in the North and in the northern part of Central Anatolia, where it grows in rocky areas, open areas and forests at $450-2240 \mathrm{~m}$ of elevation. C. orientalis subsp. szovitsii naturally grows within steppes and Quercus sp. forests at $700-2150 \mathrm{~m}$ of elevation in northern, central and eastern Anatolia [6,8] (Figure 2).

As far as the ethnobotanical uses are concerned, C. orientalis subsp. orientalis is commonly known as "Alıç, Kırmızı Alıç", while C. orientalis subsp. szovitsii is known as "Koyun Alıcı, Deli Alıç" in Anatolia $[5,8,10,11]$. It is reported that various parts (flowers, leaves, roots, fruits) of these taxa have traditionally been used in folk medicine. In East Anatolia, roots of C. orientalis subsp. orientalis are boiled and bathed in their water for the treatment of rheumatic pains and against swelling [12]; decoction of fruits are used as vasodilator and cardiotonic in the treatment of cardiac disorders [13]. It is also known that drinking infusion of flowers of subsp. szovitsii every morning on an empty stomach can treat cardiac disorders and asthma [14]. Other studies

How to cite this article: Erarslan ZB, Kültür Ş. Leaf anatomical traits of Crataegus orientalis Pall. ex M.Bieb. (Rosaceae) from Turkey. J Res Pharm. 2019; 23(5): 804-811. 
revealed that these taxa have antithrombotic, antinociceptive, antiinflammatory, and antioxidant activities [1517] owing to their content of phenolic acids, flavonoids and organic acids [19-21].

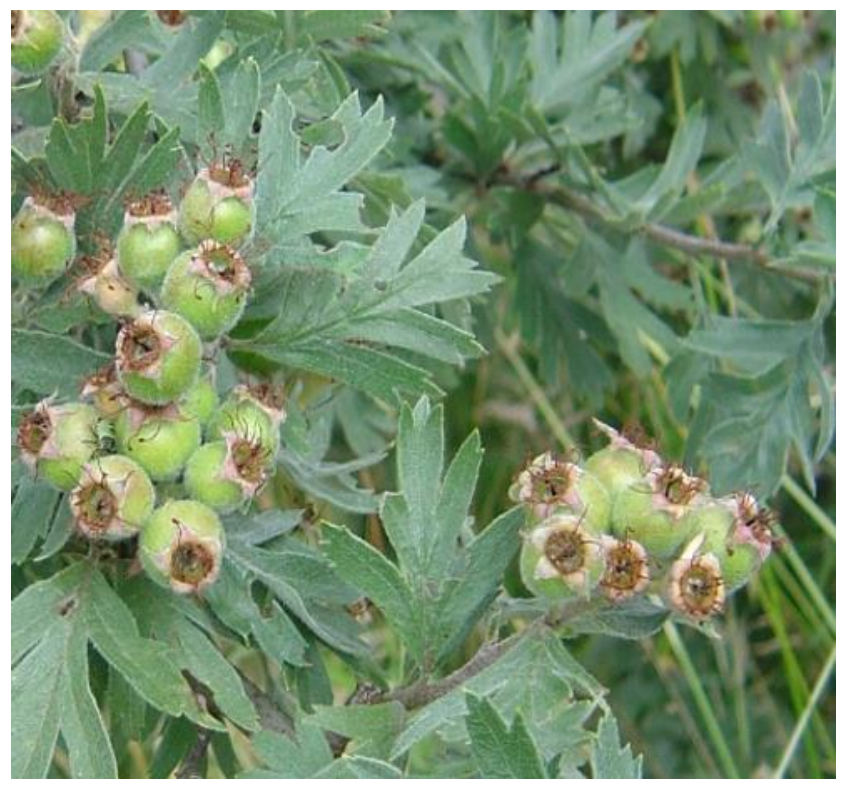

Figure 1. Fruit details of Crataegus orientalis subsp. szovitsii.

Though taxonomic problems related to the genus remain, few anatomical studies were fulfilled to provide further valuable diagnostic features. Hence, the main purpose of this study is to define the leaf anatomy of $C$. orientalis subsp. orientalis and C. orientalis subsp. szovitsii and detect distinctive anatomical features of these taxa.

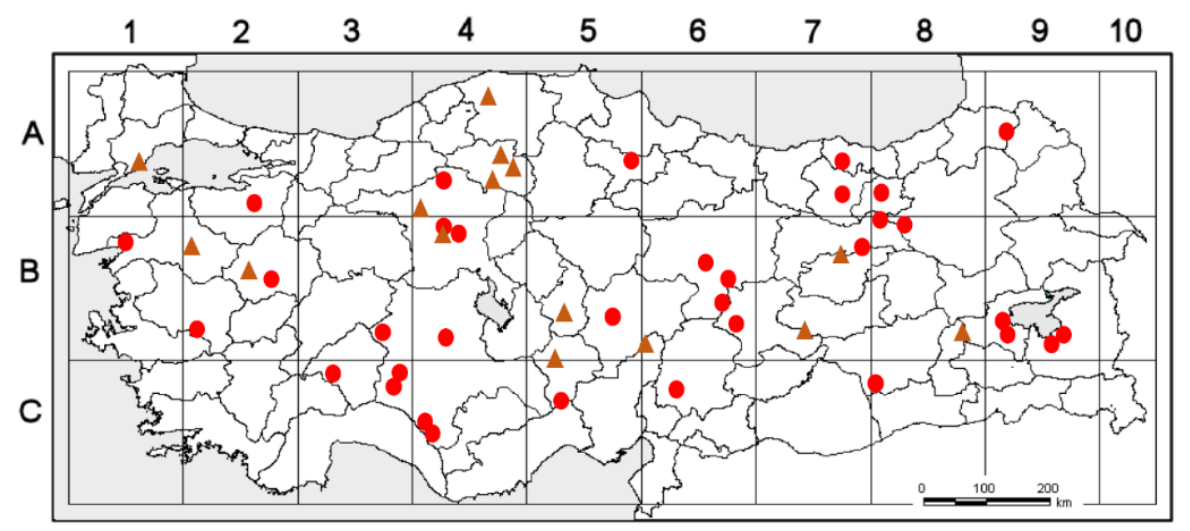

Figure 2. Distribution map of Crataegus orientalis subsp. orientalis (๑) and Crataegus orientalis subsp. szovitsii (А) in Turkey.

\section{RESULTS}

The anatomical investigation of C. orientalis subsp. orientalis revealed a dorsiventral, hypostomatic and mesomorphic leaf. In the transverse sections, both upper and lower epidermis consist of single-layered cells with a thin cuticle layer. The upper epidermal cells are bigger than the lower ones. Single simple non-glandular thick-walled trichomes, varying in length, have been observed on both leaf surfaces. The mesophyll is composed of $1-2$ layers of palisade cells under the upper epidermis and spongy cells with wide intercellular spaces. Leaf blade thickness ranges from 267.73 to $290.80 \mu \mathrm{m}$, with a mean value of $271.92 \mu \mathrm{m}$ (Figure 3).

In the midrib, which is on average $616.300 \mu \mathrm{m}$ thick, $4-5$ layers of collenchyma develop under both lower and upper epidermis. Parenchyma cells are located between the collenchyma layers and the collateral vascular bundles. Moreover, several druses and prismatic crystals of calcium oxalate were detected in the midrib and the mesophyll of the leaf. 
On the surface sections, epidermis has polygonal cells with usually straight anticlinal walls. Cyclocytic stomata, which are found only on the lower surface, are oval shaped and varying sized (Table 1). Each stoma is surrounded by $5-7$ subsidiary cells (Figure 4 ). The stomatal index for the lower surface of the lamina was calculated as 10.38 .
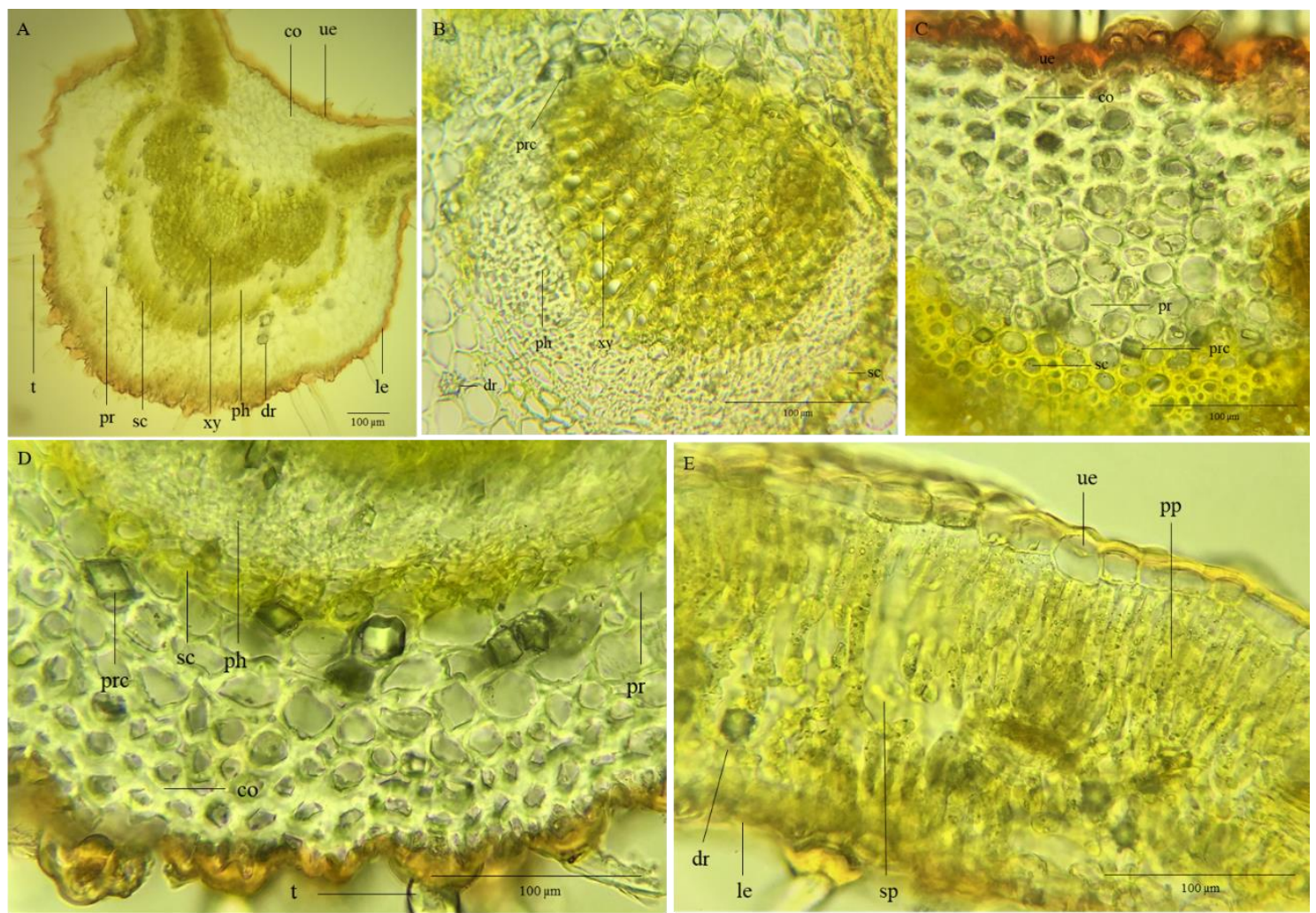

Figure 3. The transverse sections of the leaf of Crataegus orientalis subsp. orientalis; $\mathbf{A}$, the midrib, $\mathbf{B}$, vascular bundle, C, detail of midrib at upper surface, D, detail of midrib at lower surface, $\mathbf{E}$ intervascular part of the leaf blade; co collenchyma, dr druse, le lower epidermis, ph phloem, pp palisade parenchyma, pr parenchyma, prc prismatic crystal, sc schleranchyma, sp spongy parenchyma, st stomata, t non-glandular trichome, ue upper epidermis, xy xylem.
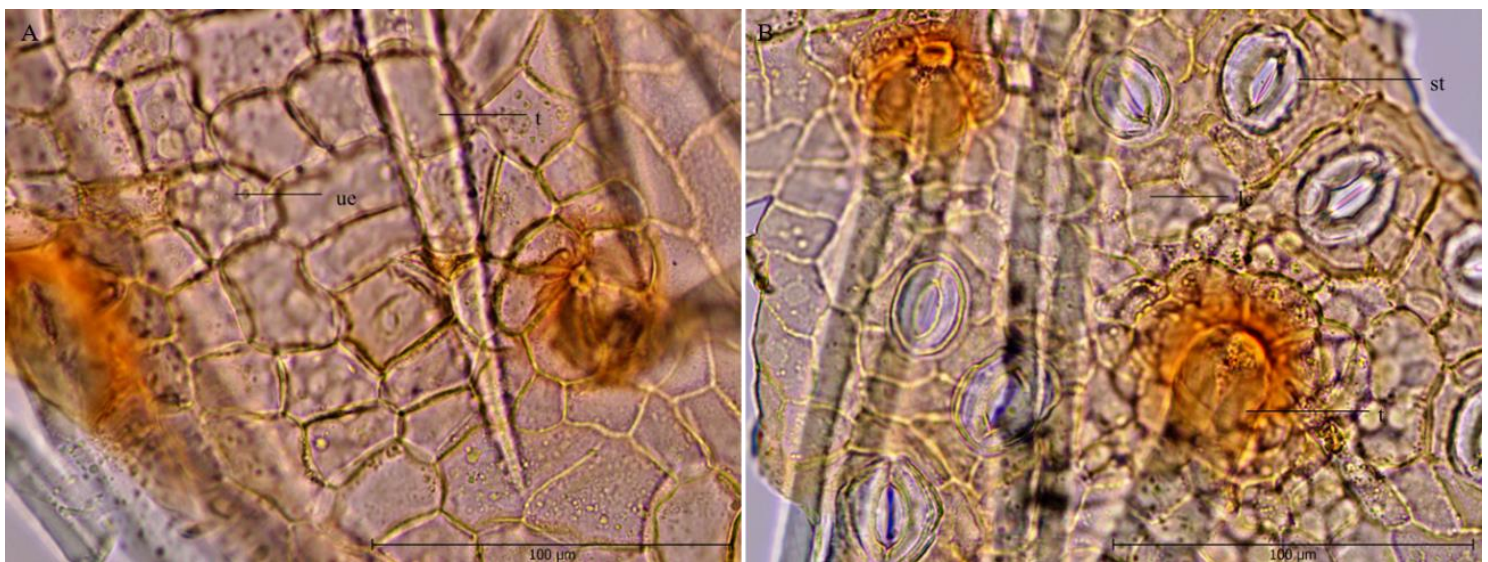

Figure 4. The surface sections of the leaf of Crataegus orientalis subsp. orientalis; $\mathbf{A}$, upper surface of the leaf, B, lower surface of the leaf; le lower epidermis, st stoma, t non-glandular trichome, ue upper epidermis.

The leaf of $C$. orientalis subsp. szovitsii was also found as dorsiventral, hypostomatic and mesomorphic like that one of $C$. orientalis subsp. orientalis. In the transverse sections, both upper and lower epidermis are one-layered and covered by a thin cuticle layer. The upper epidermal cells are bigger in size than the lower ones. The trichomes are simple single thick-walled non-glandular, varying in size and distributed on both sides of the leaf surfaces. The mesophyll comprises $1-2$ layers of palisade cells under the upper epidermis 
and spongy cells with wide intercellular spaces. The leaf blade thickness is $207.49-232.64 \mu \mathrm{m}$ with a mean value of $221.13 \mu \mathrm{m}$ (Figure 5).

Regarding the midrib region, $4-6$ layers of collenchyma are present under the upper and lower epidermis. Between the collenchyma layers and the collateral vascular bundles, parenchyma cells were observed. The leaf thickness at the midrib is on average $478.90 \pm \mu \mathrm{m}$. Many druses and prismatic crystals of calcium oxalate were also noticed in both leaf midrib and mesophyll. On the surface sections, the epidermal cells appear as polygonal in shape like those ones of C. orientalis subsp. orientalis. Similarly, stomata are oval shaped, varying sized and located only on the lower surface (Table 1). The stomatal type is also cyclocytic, with each stoma is surrounded by $5-7$ subsidiary cells (Figure 6). The stomatal index for the lower surface of the lamina was calculated as 12.33 .
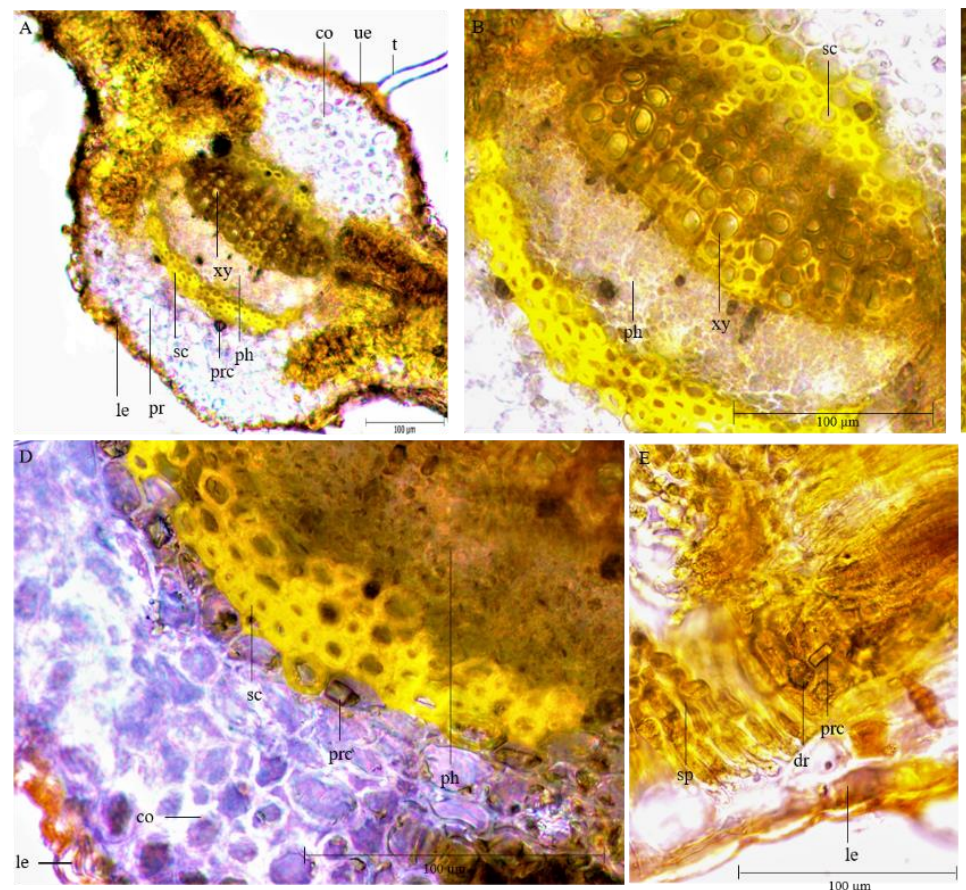
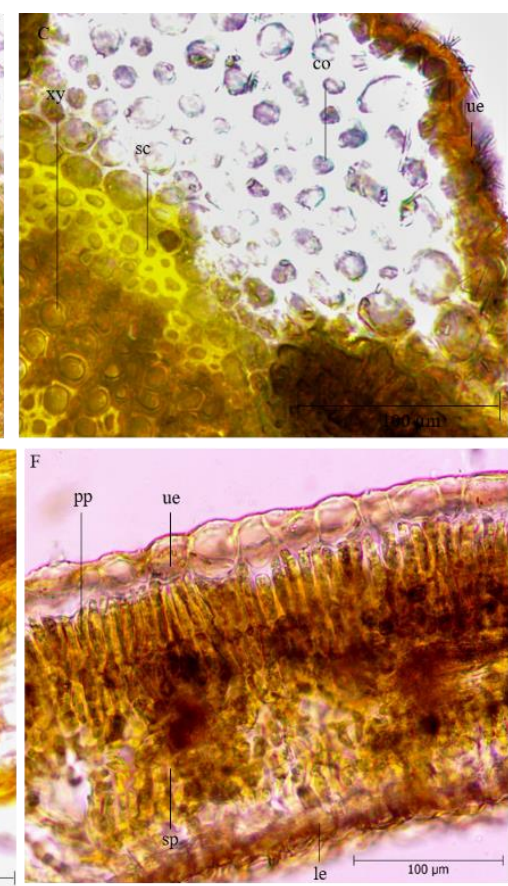

Figure 5. The transverse sections of the leaf of Crataegus orientalis subsp. szovitsii; $\mathbf{A}$, the midrib, B vascular bundle, C, detail of midrib at upper surface, D, detail of midrib at lower surface, E, F, intervascular part of the leaf blade; co collenchyma, dr druse, le lower epidermis, ph phloem, pp palisade parenchyma, pr parenchyma, prc prismatic crystal, sc schleranchyma, sp spongy parenchyma, st stomata, t non-glandular trichome, ue upper epidermis, xy xylem.
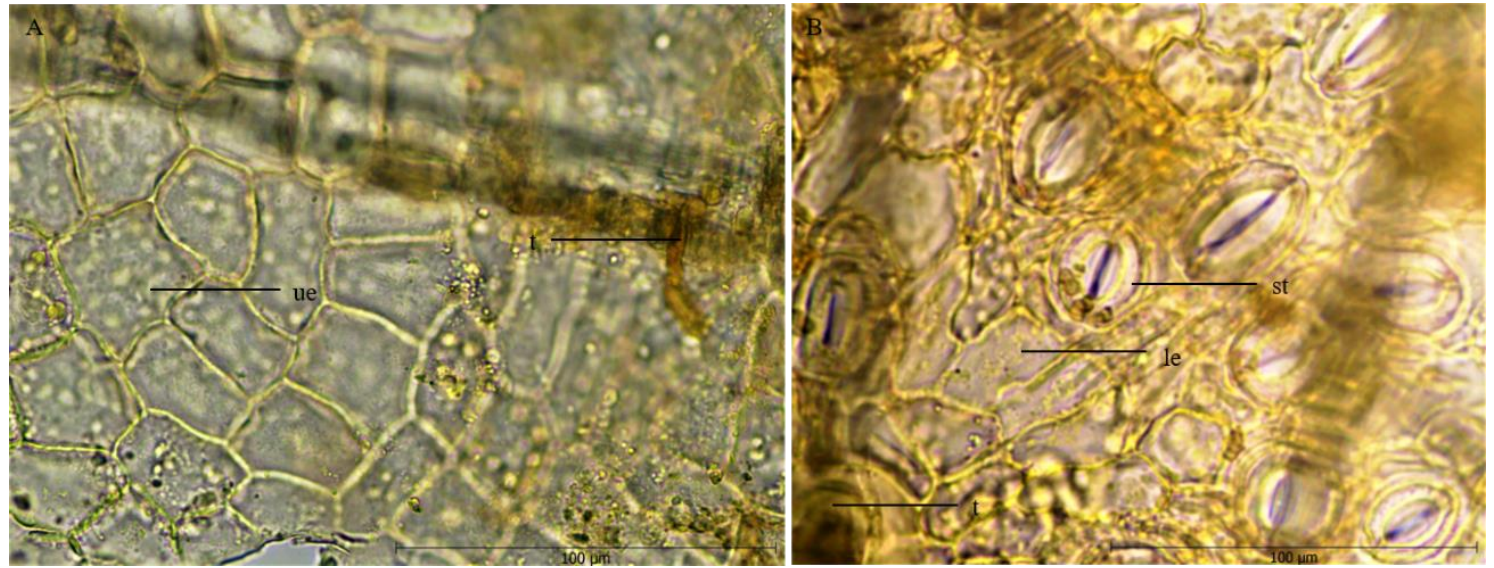

Figure 6. The surface sections of the leaf of Crataegus orientalis subsp. szovitsii; A upper surface of the leaf, B lower surface of the leaf; le lower epidermis, st stoma, $t$ non-glandular trichome, ue upper epidermis. 
Table 1. Measurements from leaf anatomical traits of C. orientalis subsp. orientalis and C. orientalis subsp. szovitsii.

$$
\text { C. orientalis subsp. orientalis } \quad \text { C. orientalis subsp. szovitsii }
$$

\begin{tabular}{|c|c|c|c|c|c|c|c|c|c|c|c|c|}
\hline & \multicolumn{3}{|c|}{ Length $(\mu \mathrm{m})$} & \multicolumn{3}{|c|}{ Width $(\mu \mathrm{m})$} & \multicolumn{3}{|c|}{ Length $(\mu \mathrm{m})$} & \multicolumn{3}{|c|}{ Width $(\mu \mathrm{m})$} \\
\hline & Min & $\operatorname{Max}$ & $\mathrm{Av}$ & Min & $\operatorname{Max}$ & Av & Min & Max & $\mathrm{Av}$ & Min & Max & $\mathrm{Av}$ \\
\hline UEC & 17.28 & 37.75 & 28.19 & 13.77 & 18.26 & 16.03 & 20.78 & 37.23 & 27.90 & 18.31 & 35.11 & 27.76 \\
\hline LEC & 12.37 & 19.05 & 16.20 & 7.82 & 17.43 & 12.22 & 12.34 & 18.34 & 15.98 & 12.73 & 21.14 & 16.32 \\
\hline LS & 23.59 & 27.72 & 26.32 & 16.83 & 26.41 & 21.94 & 27.42 & 40.77 & 31.63 & 17.53 & 24.53 & 21.32 \\
\hline PPL & & & & 72.40 & 90.68 & 80.48 & & & & 63.50 & 72.48 & 68.40 \\
\hline SPL & & & & 135.97 & 144.28 & 142.64 & & & & 92.35 & 101.52 & 95.38 \\
\hline
\end{tabular}

Abbreviations: Min Minimum, Max Maximum, Av Average, UEC Upper epidermis cell, LEC Lower epidermis cell, LS Lower stoma, PPL Palisade parenchyma layer, SPL Spongy parenchyma layer.

\section{DISCUSSION}

In the Flora of Turkey and the East Aegean Islands [6], C. orientalis was classified into two varieties: var. orientalis and var. obtusata Browicz. As a result of recent revisions, C. orientalis var. obtusata is reduced to a synonym; consequently, C. orientalis is represented by two subspecies in Turkey, C. orientalis subsp. orientalis and C. orientalis subsp. szovitsii $[5,8]$. However, discussions on this taxonomic classification continue, and various data obtained from taxonomic studies including anatomical investigations could help to clarify this issue. Thus, in this study significative anatomical features of the leaves (e.g. types of trichomes, stomata, mesophyll, crystals) of these taxa were investigated.

Shared anatomical features observed in both taxa are: dorsiventral, hypostomatic and mesomorphic leaves, cyclocytic stomata, which are surrounded by $5-7$ subsidiary cells, and presence of calcium oxalate crystals (druses and prismatic crystals). On the other hand, some differences in measurements were found regarding size of epidermal cells and stomata, width of mesophyll and stomatal index. While stomatal index is found to be fairly constant at species level, ecological factors are quite effective on the stoma size and density [22-24]. Although according to Meltcafe \& Chalk [25], simple trichomes with variation in structure and anomocytic stomatal type are found in Rosaceae family, cyclocytic stomatal type was also reported in previous studies for several genera, such as Crataegus, Pyracantha Roemer, Cydonia Mill. [26-29]. Nevertheless, anomocytic stomatal type was found in some Malus Mill. and Sibbaldia L. species [30,31]. Simple single nonglandular trichomes are characteristic for some species of Crataegus, Malus and Sorbaria A. Braun, as well as for Cydonia oblonga Mill. [28-30,32]. Similarly to our results, distrubition of stomata in some Crataegus species was only found on lower epidermis $[28,33]$.

Previous anatomical invesigations on Crataegus species from Turkey [33] highlighted the occurrence of druse crystals and prismatic crystals in the midrib of Crataegus monogyna Jacq. subsp. monogyna and in the mesophyll and epidermis of Crataegus pentagyna Waldst. \& Kit. ex Willd., while both tetragonal and prismatic crystals were reported for C. orientalis [34]. Furthermore, calcium oxalate crystals were also found in different parts of the leaf lamina in the genus Rosa L. [35] and Rosaceae family [25,36-38]. Regarding the mesophyll structure, many species of Rosa, Cotoneaster Medik., Pyrus L. and Potentilla L. have dorsiventral leaves, with palisade tissue in the upper surface and spongy parenchyma in the lower surface [35,38-41]. Conversely, isobilateral mesophyll was described for some species of the Rosaceae family [39,40,42], while Baldemir \& Güvenç [33] reported isobilateral mesophyll in C. pentagyna and dorsiventral mesophyll in C. monogyna subsp. monogyna.

\section{CONCLUSION}

Conducted studies revealed that cyclocytic and anomocytic stomata type, simple non-glandular trichomes, calcium oxalate crystals, dorsiventral or isobilateral mesophyll are the most prominent leaf features for Rosaceae family. Regarding the genus Crataegus, cyclocytic stomata type, simple single non-glandular trichomes and presence of calcium oxalate crystals can be considered as demonstrative anatomical properties which could help to clarify taxonomy of this genus. Nevertheless, to confirm the diagnostic value of these characters within the genus and among Rosaceae, further comparative anatomical studies with the other species of this genus should be fulfilled. 


\section{MATERIALS AND METHODS}

The anatomical investigation was carried out on leaf samples obtained from herbarium materials. $C$. orientalis subsp. orientalis collected from Arslanköy (İçel) (ISTE 98194) and C. orientalis subsp. szovitsii collected from Kepsut (Balıkesir) (ISTE 109913) were preserved in the Herbarium of Istanbul University Faculty of Pharmacy. Leaves were pretreated with immersed in warm water. Transverse sections and surficial sections were hand-cut with a razor, stained with Sartur reagent (lactic acid, Sudan III, aniline, iodine, potassium iodide, alcohol and water) [43,44] and observed under light microscope. For the anatomical investigations and measurements, at least 10 individual specimens and 15 leaves per individual specimens were used. Detailed photographs were taken by Canon Power Shot A640 and required measurements (Table 1) were made by KAMERAM $\odot$ software. The stomatal index (SI) was calculated according to the following formula [45]: SI = $(S / S+E) \times 100$, where ' $S$ ' refers to the number of stomata per unit area and ' $E$ ' refers to the number of epidermal cells in the same unit area.

Acknowledgements: We are grateful to Ebru Özdemir Nath for useful herbarium material and plant photograph.

Author contributions: Concept - Z.B.E., Ş.K.; Design - Z.B.E., Ş.K.; Supervision - Z.B.E., Ş.K.; Resources -Ş.K.; Materials - Ş.K; Data Collection and/or Processing - Z.B.E., Ş.K.; Analysis and/or Interpretation - Z.B.E., Ş.K.; Literature Search - Z.B.E.; Writing - Z.B.E.; Critical Reviews - Z.B.E.; Ş.K.

Conflict of interest statement: The authors declared no conflict of interest.

\section{REFERENCES}

[1] Reveal JL. Newly required infrafamilial names mandated by changes in the Code of nomenclature for algae, fungi and plants. Phytoneuron. 2010; 2012(33): 1-31.

[2] Reveal JL. An outline of a classification scheme for extant flowering plants. Phytoneuron. 2012; 2012(37): 1-221.

[3] Dönmez AA. Taxonomic notes on the genus Crataegus (Rosaceae) in Turkey. Bot J Linn Soc. 2007; 155(2): 231-240. [CrossRef]

[4] Yılmaz KU, Yanar M, Ercişli S, Şahiner H, Taşkın T, Zengin Y. Genetic relationships among some Hawthorn (Crataegus spp.) species and genotypes. Biochem Genet. 2010; 48(8-9): 873-878. [CrossRef]

[5] Aslan S. Crataegus L. In: Güner A, Aslan S, Ekim T, Vural M, Babaç MT (Eds). Türkiye Bitkileri Listesi (Damarlı Bitkiler). Nezahat Gökyiğit Botanik Bahçesi ve Flora Araştırmaları Derneği Yayını, İstanbul, 2012, pp. 798-801.

[6] Browicz K. Crataegus (Rosaceae). In: Davis PH. (Ed) Flora of Turkey and the East Aegean Islands, Vol. 4. Edinburgh University Press, Edinburgh, 1972, pp. 133-147.

[7] Dönmez AA. The genus Crataegus L. (Rosaceae) with special reference to hybridisation and biodiversity in Turkey. Turk J Bot. 2004; 28: 29-37.

[8] Özkan NG, Aslan S, Fırat M. Crataegus L. In: Akkemik Ü. (Ed). Türkiye' nin Doğal, Egzotik Ağaç ve Çalıları II. Orman Genel Müdürlüğü Yayınları, Ankara, 2014, pp. 318-341.

[9] Christensen KI. Revision of Crataegus Sect. Crataegus and Nothosect. Crataeguineae (Rosaceae-Maloideae) in the Old World. Syst Bot Monogr. 1992; 35: 1-199. [CrossRef]

[10] Tuzlacı E. Türkiye Bitkileri Sözlüğü, second ed., Alfa Yayınları, İstanbul, Turkey, 2011, pp. 923.

[11] Baytop T, Türkçe Bitki Adları Sözlüğü, Türk Dil Kurumu Yayınları, Ankara, Turkey, 1994.

[12] Behçet L, Arrk M. An ethnobotanical investigation in East Anatolia (Turkey). Tr J Nature Sci. 2013; 2(1): 1-14.

[13] Polat R, Satıl F, Çakılcığlu U. Medicinal plants and their use properties of sold in herbal market in Bingöl (Turkey) district. Biodicon. 2011; 4(3): 25-35.

[14] Polat R. Ethnobotanical study on medicinal plants in Bingöl (City center) (Turkey). J Herb Med. 2018. [CrossRef]

[15] Arslan R, Bor Z, Bektaş N, Meriçli AH, Öztürk Y. Antithrombotic effects of ethanol extract of Crataegus orientalis in the carrageenan-induced mice tail thrombosis model. Thromb Res. 2011; 127(3): 210-213. [CrossRef]

[16] Bor Z, Arslan R, Bektaş N, Pırıldar S, Dönmez AA. Antinociceptive, antiinflammatory, and antioxidant activities of the ethanol extract of Crataegus orientalis leaves. Turk J Med Sci. 2012; 42(2): 315-324. [CrossRef] 
[17] Özyürek M, Bener M, Güçlü K, Dönmez AA, Selçuk SS, Pırıldar S, Meriçli AH, Apak R. Evaluation of antioxidant activity of Crataegus species collected from different regions of Turkey. Rec Nat Prod. 2012; 6(3): 263-277.

[18] Hatipoğlu M, Sağlam M, Köseoğlu S, Köksal E, Keleş A, Esen HH. The effectiveness of Crataegus orientalis M. Bieber. (Hawthorn) extract administration in preventing alveolar bone loss in rats with experimental periodontitis. PLoS One. 2005; 10(6): 1-11. [CrossRef]

[19] Gündoğdu M, Özrenk K, Ercişli S, Kan T, Kodad O, Hegedus A. Organic acids, sugars, vitamin C content and some pomological characteristics of eleven hawthorn species (Crataegus spp.) from Turkey. Biol Res. 2014; 47(1): 1-5. [CrossRef]

[20] Meriçli AH, Melikoğlu G. Investigations on Turkish Crataegus species. Acta Pharmaceutica Turcica. 2002; 44(3): 169173.

[21] Çoklar H, Akbulut M, Kılınç S, Yıldırım A, Alhassan I. Effect of freeze, oven and microwave pretreated oven drying on color, browning index, phenolic compounds and antioxidant activity of Hawthorn (Crataegus orientalis) fruit. Not Bot Horti Agrobo. 2018; 46(2): 449-456. [CrossRef]

[22] Elias P. Stomata density and size of apple trees growing in irrigated and nonirrigated conditions. Biologia. 1995; 50(1): 115-118.

[23] Çağlar S, Sütyemez M, Bayazit S. Stomatal density in some selected Walnut (Juglans regia) types. Mediterr Agric Sci. 2004; 17(2): 169-174 (article in Turkish with an abstract in English).

[24] Tanker N, Farmasötik Botanik (Bitkisel Drogların Makroskopik ve Mikroskopik Özellikleri), second ed., Ankara Üniversitesi Basımevi, Ankara, Turkey, 2007.

[25] Metcalfe CR, Chalk L. Anatomy of the Dicotyledones, vol. 1., Clarendon Press, Oxford, United Kingdom, 1950.

[26] Uzunova K, Mladenova R. A comparative foliar epidermis investigation of the Bulgarian species of genera Cotoneaster Med., Pyracantha M. J. Roem. and Mespilus L. (Rosaceae, Maloidae). Phytol Balc. 2000; 6(2-3): 179-193.

[27] Yentür S. Bitki Anatomisi, third ed., İstanbul Üniversitesi Yayınları, İstanbul, 2003, pp. 126.

[28] Ganeva TS, Uzunova K, Koleva D. Comparative leaf epidermis investigation in species of genus Crataegus L. (Rosaceae). Feddes Repert. 2009; 120(3-4): 169-184. [CrossRef]

[29] Ganeva T. Leaf epidermis structure in Cydonia oblonga Mill. (Rosaceae). Biotechnol Biotechnol Equip. 2009; 23: $965-$ 967. [CrossRef]

[30] Ganeva TS, Uzunova K. Comparative leaf epidermis study in species of genus Malus Mill. (Rosaceae). Bot Serb. 2010; 34(1): 45-49.

[31] Tahir SS, Rajput MTM. S.E.M. structure distribution and taxonomic significance of foliar stomata in Sibbaldia L. species (Rosaceae). Pak J Bot. 2009; 41(5): 2137-2143.

[32] Song JH, Hong SP. Comparative petiole anatomy of the tribe Sorbarieae (Rosaceae) provide new taxonomically informative characters. Nord J Bot. 2018; 36(5): 1-14. [CrossRef]

[33] Baldemir A, Güvenç A. Morphological and anatomical studies on Crataegi folium cum flore which sold in herbalists in Adana and Ankara. J Fac Pharm Ankara. 2010; 39(2): 89-111 (article in Turkish with an abstract in English).

[34] Demiray H. Calcium oxalate crystals of some Crataegus (Rosaceae) species growing in Aegean region. Biologia. 2007; 62(1): 46-50. [CrossRef]

[35] Kültür Ş. PhD Thesis. Kuzey-Batı Türkiye' de yetişen yabani Rosa türleri üzerinde farmasötik botanik bir araştırma. Department of Pharmaceutical Botany, Faculty of Pharmacy, Istanbul University, İstanbul, Turkey, 1998.

[36] Jackson BP, Snowdon DW, Atlas of Microscopy of Medicinal Plants, Culinary Herbs and Spices, 1st ed., Belhaven Press, India, 1990.

[37] Lersten NR, Homrner HT. Calcium oxalate crystal types and trends in their distribution patterns in leaves of Prunus (Rosaceae: Prunoideae). Plant Syst Evol. 2000; 224(1): 83-96. [CrossRef]

[38] Faghir MB, Attar F, Ertter B. Foliar anatomy of the genus Potentilla L. (Rosaceae) in Iran and its taxonomic implication. Iran J Sci Technol A. 2011; 35(3): 243-256. [CrossRef]

[39] Fatemi N, Attar F, Assareh MH, Hamzeh'ee B. Comparative anatomy of leaf and rachis of Rosa L. (Rosaceae) in Iran as taxonomical implication. Iran J Bot. 2008; 14(2): 156-164.

[40] Zamani A, Attar F, Ghahreman A, Maroofi H. Anatomical studies of the genus Pyrus L. (Rosaceae) in Iran and its taxonomical implications. Iran J Bot. 2008; 14(2): 132-142. 
[41] Niaki NR, Attar F, Maroofi H. Anatomical studies on fourteen species of the genus Cotoneaster L. (Rosaceae) in Iran. Iran J Bot. 2009; 15(1): 96-104.

[42] Vafadar M, Attar F, Maroofi H, Aghabeigi F. Leaf anatomical study of the genus Amygdalus L. (Rosaceae) in Iran and its taxonomical implication. Iran J Bot. 2008; 14(2): 143-155.

[43] Çelebioğlu S, Baytop T. A new reagent for microscopical investigation of plant. Publication of the Institute of Pharmacognosy. 1949; 10: 301.

[44] Özkan Y, Türk Farmakopesi 2017, Genel monograflar I, 1st ed., T.C. Sağlık Bakanlığı Yayını, Ankara, Turkey, 2018.

[45] Salisbury EJ. On the cause and ecological significance of stomatal frequency with special reference to the woodland flora. Philos T R Soc B. 1927; 216: 1-65.

This is an open access article which is publicly available on our journal's website under Institutional Repository at http://dspace.marmara.edu.tr. 